\title{
PEREKRUTAN DOSEN TETAP DAN TIDAK TETAP DI UNIVERSITAS MENGGUNAKAN METODE ANALYTICAL HIERARCHY PROCESS (AHP)
}

\author{
Darsin ${ }^{1}$, Muhardi $^{2}$ \\ Teknik Informatika ${ }^{12}$ \\ Universitas Megou Pak Tulang Bawang ${ }^{12}$ \\ Lampung \\ Jl. Lintas Timur Sumatera Tiuh Tohou Menggala - Tulang Bawang \\ E-mail : umptb.darsin@gmail.com, ardyardy68@yahoo.co.id,
}

\begin{abstract}
ABSTRAK
Universitas Megou Pak Tulang Bawang (UMPTB) merupakan perguruan tinggi swasta yang telah berdiri sejak tahun 2006. Dengan lokasi di salah satu Kabupaten di Provinsi Lampung tepatnya di Kabupaten Tulang Bawang. Proses seleksi calon dosen di Universitas Megou Pak Tulang Bawang masih dilakukan secara manual. Diperlukan system pendukung keputusan (SPK) guna meningkatkan efektivitas pengambilan keputusan serta mengurangi subyektivitas dalam proses pengambilan keputusan. Salah satunya adalah metode AHP (Analytical Hierarchy Process). Adapun kriteria yang digunakan untuk proses seleksi dosen tetap dan dosen tidak tetap adalah IPK, Nilai TPA (Tes Potensi Akademik), Nilai TOEFL (Test Of English as a Foreign Language), Microteaching, dan Wawancara. Metode AHP (Analytical Hierarchy Process) sering digunakan karena metode pendukung keputusan ini akan menguraikan masalah multi factor atau multi kriteria yang kompleks menja disuatu hirarki. Dengan menggunakan metode AHP perekrutan dosen menjadi lebih efektif, selektif, dan terintegrasi dalam upaya mencari dosen tetap dan tidak tetap yang berkualitas di Universitas Megou Pak Tulang Bawang.
\end{abstract}

Kata Kunci : Sistem Pendukung Keputusan, Dosen Tetap, Dosen Tidak Tetap, Universitas Megou Pak Tulang Bawang, Analytical Hierarchy Process

\section{ABSTRACT}

The Megow Pak Tulang Bawang University is a private tertiary institution which was established in 2006. With a location in one of the districts in Lampung Province pprecisely in Tulang Bawang Regency. The selection process for the megou Pak Tulang Bawang University is still done manually. is reguired decision support system in order to increase the effectiveness of decision making and reduce subjectivity in the decision making process. One of them is the AHP (Analytical Hierarchy Process) method. The criteria used for the selection process of permanent lecturers and non-permanent lecturers are GPA, TPA (Academic Potential Test), TOEFL (Test of English as a Foreign Language), Microteaching, and Interview. The AHP (Analytical Hierarchy Process) method is often used because this decision support method will elaborate multi-factor or complex multi-criteria problems into a hierarchy. By using AHP method, lecturer recruitment becomes more effective, selective, and integrated in the effort to find qualified and permanent lecturers at Megou Pak Tulang Bawang University.

Keyword : Decision Support System, Permanent Lecturer, Non Permanent Lecturer, Megou Pak Tulang Bawang University, Analytical Hierarchy Process 


\section{PENDAHULUAN}

Universitas Megou Pak Tulang Bawang merupakan satu-satunya Universitas di wilayah Menggala, Tulang Bawang yang didirikan berdasarkan Surat Keputusan Menteri Pendidikan Nasional Republik Indonesia No252/D/O/2006 tertanggal 30 Oktober 2006, tentang alih Pelatihan Profesional (PPKP) di Yogyakarta menjadi Universitas Megou Pak Tulang Bawang di Menggala yang diselenggarakan oleh Yayasan Megou Pak Tulang Bawang.

Proses seleksi calon dosen di Universitas Megou Pak Tulang Bawang masih dilakukan secara manual, semua data dan file tidak didokumentasikan dengan baik, proses penilaian masih menggunakan aplikasi Microsoft Excel. Hal ini dinilai kurang baik karena tingkat kesalahan sangat tinggi maka akan berdampak pada analisis data tidak valid.

Diperlukan sistem pendukung keputusan (SPK) guna meningkatkan efektivitas pengambilan keputusan serta mengurangi subyektivitas dalam proses pengambilan keputusan. Ada berbagai macam metode yang dapat digunakan untuk menunjang suatu keputusan, salah satunya adalah metode AHP (Analytical Hierarchy Process). Metode ini sering digunakan karena metode pendukung keputusan ini akan menguraikan masalah multi faktor atau multi kriteria yang1. kompleks menjadi suatu hirarki. Dengan hirarki, suatu masalah yang kompleks dapat diuraikan ke dalam kelompok-kelompoknya yang kemudian2. diatur menjadi suatu bentuk hirarki sehingga3. permasalahan akan tampak lebih terstruktur dan sistematis. Adapun kriteria yang digunakan untuk proses seleksi adalah IPK, Nilai TPA (Tes Potensi Akademik), Nilai TOEFL (Test Of English as a4. Foreign Language), Microteaching, dan Wawancara.

\subsection{PERUMUSAN MASALAH}

Perumusan masalah dari penelitian tugas akhir ini adalah sebagai berikut :

1. Bagaimana menyajikan informasi untuk mempermudah dalam proses penerimaan dosen tetap dan tidak tetap.

2. Bagaimana membangun sebuah sistem pendukung keputusan untuk membantu pihak Universitas Megou Pak Tulang Bawang dalam pengambilan keputusan untuk seleksi penerimaan dosen tetap dan tidak tetap.

\subsection{BATASAN MASALAH}

Penulis membatasi ruang lingkup masalah yang akan dibahas sebagai berikut :

1. Penelitian ini membahas tentang proses pengambilan keputusan untuk menentukan penerimaan dosen tetap dan tidak tetap di Universitas Megou Pak Tulang Bawang ;

2. Penelitian ini menggunakan metode AHP untuk mendukung keputusan.

\subsection{TUJUAN PENELITIAN}

Tujuan penelitian ini adalah membangun sistem penunjang keputusan perekrutan dosen yang lebih efektif, selektif, dan terintegrasi dalam upaya mencari dosen tetap dan tidak tetap yang berkualitas.

\section{TINJAUAN PUSTAKA}

2.1 Tahapan Analytical Hierarchy Process (AHP) Langkah-langkah dalam metode AHP adalah sebagai berikut :

- Mendefiniskan Masalah

Mendefinisikan masalah dan menentukan solusi yang diinginkan, lalu menyusun hirarki dari permasalahan yang dihadapi. Penyusunan hirarki yaitu menetapkan tujuan yang merupakan sasaran sistem secara keseluruhan pada level teratas.

- Menetapkan Prioritas Elemen

Berikut ini adalah langkah-langkah dalam menetapkan prioritas elemen :

Membuat perbandingan berpasangan, yaitu membandingkan elemen secara berpasangan sesuai kriteria yang diberikan.

Matriks perbandingan berpasangan diisi menggunakan bilangan untuk mempresentasikan kepentingan relatif dari suatu elemen terhadap elemen lainnya.

\section{- Sintesis}

Prioritas secara keseluruhan diperoleh dengan melakukan sintesis pertimbangan terhadap perbandingan berpasangan.

Dalam langkah ini, hal-hal yang dilakukan adalah :

1. Menjumlahkan nilai-nilai dari setiap kolom pada matriks.

2. Membagi setiap nilai dari kolom dengan total kolom yang bersangkutan untuk memperoleh normalisasi matriks.

3. Menjumlahkan nilai-nilai dari setiap baris dan membaginya dengan jumlah elemen untuk mendapatkan nilai rata-rata.

- Mengukur Konsistensi 
Tingkat konsistensi penting untuk diperhatikan dalam pembuatan keputusan. Dalam tahap ini matriks dibuat dengan mengalikan nilai bobot prioritas dengan matriks perbandingan berpasangan. Hasilnya masing-masing baris dijumlah, kemudian hasilnya dibagi dengan masing-masing nilai prioritas kriteria sebanyak $\lambda_{1}, \lambda_{2}, \lambda_{3} \ldots \ldots, \lambda_{\mathrm{n}}$

- Menghitung Lambda Max dengan rumus :

$\lambda \max =\Sigma \lambda$

$$
\mathrm{n}
$$

- Menghitung Consistensy Indeks (CI) dengan rumus :

$$
\mathrm{CI}=\frac{\lambda \max -\mathrm{n}}{\mathrm{n}-1}
$$

Keterangan :

$\mathrm{n}=$ banyaknya elemen.

- Menghitung Concistency Rasio (CR) dengan rumus:

$$
\mathrm{CR}=\mathrm{CI} \overline{\mathrm{IR}}
$$

Keterangan :

$\mathrm{CR}=$ Consistency Rasio, $\mathrm{CI}=$ Consistency Index, dan

$\mathrm{IR}=$ Index Random Consistency

- Memeriksa Consistency Hirarki.

nilai lebih dari $100 \%$, maka penilaian data judgement harus diperbaiki. Namun jika rasio konsistensi (CI/IR) kurang atau sama dengan 0,1 maka hasil perhitungan bisa dinyatakan benar.

Daftar Index Random Consistency dapat dilihat pada tabel berikut.

Tabel 2.1 Index Random Consistency

\begin{tabular}{|c|c|c|c|c|c|c|c|c|c|c|c|c|c|c|}
\hline$n$ & 1,2 & 3 & 4 & 5 & 6 & 7 & 8 & 9 & 10 & 11 & 12 & 13 & 14 & 15 \\
\hline $\mathbb{R}$ & 0 & 0,58 & 0,9 & 1,12 & 1,24 & 1,32 & 1,41 & 1,45 & 1,49 & 1,51 & 1,48 & 1,56 & 1,57 & 1,6 \\
\hline
\end{tabular}

\section{Metode Penelitian}

\subsection{Analisis Permasalahan}

Berikut adalah kriteria yang digunakan untuk perekrutan dosen tetap dan tidak tetap di Univeritas Megou Pak Tulang Bawang:

1. IPK

2. TOEFL

3. Microteaching

4. TPA (Tes Potensi Akademik)

5. Wawancara

6. Pengalaman
Menghitung nilai bobot kriteria dengan cara membuat matriks perbandingan berpasangan. Tahap ini dilakukan penilaian perbandingan antara kriteria yang satu dengan kriteria lainnya.

Tabel 3.1 Membuat Matriks Perbandingan Berpasangan Dosen Tetap

\begin{tabular}{|c|c|c|c|c|c|c|}
\hline & & & & & & \\
& IPK & Toefl & Microteaching & TPA & Wawancara & Pengalaman \\
\hline IPK & 1,00 & 2,00 & 3,00 & 3,00 & 4,00 & 4,00 \\
\hline Toefl & 0,50 & 1,00 & 2,00 & 3,00 & 3,00 & 4,00 \\
\hline Microteaching & 0,33 & 0,50 & 1,00 & 2,00 & 3,00 & 3,00 \\
\hline TPA & 0,33 & 0,33 & 0,50 & 1,00 & 2,00 & 3,00 \\
\hline Wawancara & 0,25 & 0,33 & 0,33 & 0,50 & 1,00 & 2,00 \\
\hline Pengalaman & 0,25 & 0,25 & 0,33 & 0,33 & 0,50 & 1,00 \\
\hline Total & $\mathbf{2 , 6 7}$ & $\mathbf{4 , 4 2}$ & $\mathbf{7 , 1 7}$ & $\mathbf{9 , 8 3}$ & $\mathbf{1 3 , 5 0}$ & $\mathbf{1 7 , 0 0}$ \\
\hline
\end{tabular}

Tabel 3.2 Membuat Matriks Perbandingan Berpasangan Dosen Tidak Tetap

\begin{tabular}{|c|c|c|c|c|c|c|}
\hline & IPK & Toet & Microteaching & TPA & Wawancara & Pengalaman \\
\hline PK & 1,00 & 2,00 & 2,00 & 3,00 & 4,00 & 4,00 \\
\hline Toefl & 0,50 & 1,00 & 2,00 & 2,00 & 3,00 & 4,00 \\
\hline Microteaching & 0,50 & 0,50 & 1,00 & 2,00 & 2,00 & 3,00 \\
\hline TPA & 0,33 & 0,50 & 0,50 & 1,00 & 2,00 & 2,00 \\
\hline Wawancara & 0,25 & 0,33 & 0,50 & 0,50 & 1,00 & 2,00 \\
\hline Pengaaman & 0,25 & 0,25 & 0,33 & 0,50 & 0,50 & 1,00 \\
\hline Total & 2,83 & 4,50 & 6,33 & 9,00 & 12,50 & 16,00 \\
\hline
\end{tabular}

Melakukan sintesis pertimbangan terhadap perbandingan berpasangan. Dalam langkah ini, hal-hal yang dilakukan adalah :

\begin{tabular}{|c|c|c|c|c|c|c|c|c|}
\hline & PRK & Toefl & Microteaching & TA & Wawancara & Pengahman & Jumlah & PV \\
\hline IPK & 0,38 & 0,45 & 0,42 & 0,31 & 0,30 & 0,24 & 2,08 & 0,35 \\
\hline Toefl & 0,19 & 0,23 & 0,28 & 0,31 & 0,22 & 0,24 & 1,46 & 0,24 \\
\hline Microteaching & 0,13 & 0,11 & 0,14 & 0,20 & 0,22 & 0,18 & 0,98 & 0,16 \\
\hline $\mathrm{TPA}$ & 0,13 & 0,08 & 0,07 & 0,10 & 0,15 & 0,18 & 0,70 & 0,12 \\
\hline Waxancara & 0,09 & 0,08 & 0,05 & 0,05 & 0,07 & 0,12 & 0,46 & 0,08 \\
\hline Pengealnan & 0,09 & 0,06 & 0,05 & 0,03 & 0,04 & 0,06 & 0,33 & 0,05 \\
\hline Total & 1,00 & 1,00 & 1,00 & 1,00 & 1,00 & 1,00 & 6,00 & 1,00 \\
\hline
\end{tabular}

Tabel 3.3 Membuat Sintesis Pertimbangan Dosen Tetap

Tabel 3.4 Membuat Sintesis Pertimbangan Dosen Tidak Tetap 


\begin{tabular}{|c|c|c|c|c|c|c|c|c|}
\hline & $\mathrm{IPK}$ & Toet & Mirotedching & $\mathbb{P A}$ & Wawanarata & Pengalanan & JIMLAH & PV \\
\hline PRK & 0,35 & 0,44 & 0,32 & 0,33 & 0,32 & 0,25 & 2,01 & 0,33 \\
\hline Toet & 0,18 & 0,22 & 0,32 & 0,22 & 0,24 & 0,25 & 1,42 & 0,24 \\
\hline Miroteaching & 0,18 & 0,11 & 0,16 & 0,22 & 0,16 & 0,19 & 1,01 & 0,17 \\
\hline TPA & 0,12 & 0,11 & 0,08 & 0,11 & 0,16 & 0,13 & 0,70 & 0,12 \\
\hline Wawancara & 0,09 & 0,07 & 0,08 & 0,06 & 0,08 & 0,13 & 0,50 & 0,08 \\
\hline Pengahaman & 0,09 & 0,05 & 0,05 & 0,06 & 0,04 & 0,06 & 0,35 & 0,06 \\
\hline Total & 1,00 & 1,00 & 1,00 & 1,00 & 1,00 & 1,00 & 6,00 & 1,00 \\
\hline
\end{tabular}

Melakukan perhitungan tiap baris dengan menggunakan matriks. Dalam tahap ini matriks dibuat dengan mengalikan nilai bobot prioritas pada Tabel 3.2 dengan matriks perbandingan berpasangan Tabel 3.1. Hasilnya masing-masing baris dijumlah, kemudian hasilnya dibagi dengan masing-masing nilai prioritas kriteria sebanyak $\lambda_{1}, \lambda_{2}, \lambda_{3} \ldots \ldots, \lambda_{\text {n. }}$

Tabel 3.5 Perhitungan Matriks Dosen Tetap

\begin{tabular}{|c|c|c|c|c|c|c|c|c|c|}
\hline & PRK & Toet & Microteaching & TPA & Wawancara & Pengalaman & PV & $\begin{array}{c}\text { Hasil } \\
\text { perkalann } \\
\text { matriks }\end{array}$ & $\begin{array}{c}\text { pembagian } \\
(\lambda)\end{array}$ \\
\hline PRK & 1,00 & 2,00 & 3,00 & 3,00 & 4,00 & 4,00 & 0,35 & 2,19 & 6,32 \\
\hline Toefl & 0,50 & 1,00 & 2,00 & 3,00 & 3,00 & 4,00 & 0,24 & 1,54 & 6,34 \\
\hline Microteaching & 0,33 & 0,50 & 1,00 & 2,00 & 3,00 & 3,00 & 0,16 & 1,02 & 6,28 \\
\hline TPA & 0,33 & 0,33 & 0,50 & 1,00 & 2,00 & 3,00 & 0,12 & 0,11 & 6,12 \\
\hline Wawancara & 0,25 & 0,33 & 0,33 & 0,50 & 1,00 & 2,00 & 0,08 & 0,47 & 6,09 \\
\hline Pengalaman & 0,25 & 0,25 & 0,33 & 0,33 & 0,50 & 1,00 & 0,05 & 0,33 & 6,12 \\
\hline Total & 2,67 & 4,42 & 7,17 & 9,83 & 13,50 & 17,00 & & & 37,27 \\
\hline
\end{tabular}

Tabel 3.6 Perhitungan Matriks Dosen Tidak

Tetap

\begin{tabular}{|c|c|c|c|c|c|c|c|c|c|}
\hline & $\mathbb{P K}$ & Toetl & Miroveaching & $\mathbb{P A}$ & Tlaraxarar & Pengananan & PV & Hasikalilla & Permagaran \\
\hline $\mathbb{P K}$ & 1,00 & 2,00 & 2,00 & 3,00 & 4,00 & 4,00 & 0,33 & 2,07 & 6,17 \\
\hline Toth & 0,50 & 1,00 & 2,00 & 2,00 & 3,00 & 4,00 & 0,24 & 1,46 & 6,17 \\
\hline Iivotedring & 0,50 & $0,0,0$ & 1,00 & 2,00 & 2,00 & 3,00 & 0,17 & 1,03 & 6,11 \\
\hline $\mathbb{P A}$ & 0,33 & 0,050 & 0,50 & 1,00 & 2,00 & 2,00 & 0,12 & 0,2 & 6,12 \\
\hline Waraxarara & 0,25 & 0,33 & 0,50 & 0,50 & 1,0 & 2,00 & 0,08 & 0,51 & 6,08 \\
\hline Penglammn & 0,25 & 0,25 & 0,33 & 0,50 & 0,50 & 1,00 & 0,06 & 0,36 & 6,08 \\
\hline Total & 2.83 & 4,80 & 6,33 & 9,00 & 12,00 & 16,000 & 1,00 & 6,14 & 36,74 \\
\hline
\end{tabular}

Menghitung Lambda Max dengan rumus :

$$
\begin{aligned}
\lambda \max & =\frac{\Sigma \lambda}{\mathrm{n}} & \lambda \max & =\frac{\Sigma \lambda}{\mathrm{n}} \\
& =\frac{37,27}{6} & & =\frac{36,75}{6} \\
& =6,21 & & =6,13
\end{aligned}
$$

Menghitung Consistensy Indeks (CI) dengan rumus :

$$
\begin{aligned}
\text { CI Dosen Tetap } & =\frac{\lambda \max -\mathrm{n}}{\mathrm{n}-1} & \text { CI Dosen T.Tetap } & =\frac{\lambda \max -\mathrm{n}}{\mathrm{n}-1} \\
& =\frac{6,21-6}{6-1} & & =\frac{6,21-6}{6-1} \\
& =0,04 & & =0,04
\end{aligned}
$$

Menghitung Concistency Rasio (CR) dengan rumus :

$$
\begin{aligned}
& \text { CR Dosen Tetap }=\mathrm{CI} \quad \mathrm{CR} \text { Dosen } \mathrm{T} \text { Tetap }=\mathrm{CI} \\
& \overline{\mathrm{IR}} \quad \overline{\mathrm{IR}} \\
& =0,04 \quad=0,04 \\
& \overline{1,24} \overline{1,24} \\
& =0,03 \quad=0,03
\end{aligned}
$$

Setelah menghitung nilai bobot kriteria, selanjutnya menentukan Prioritas Sub Kriteria. Perhitungan subkriteria dilakukan terhadap subsub dari semua kriteria yaitu terdapat 4 kriteria yang berarti akan ada 4 perhitungan prioritas.

- Menghitung Prioritas Subkriteria dari IPK

Tabel 3.7 Perhitungan Matriks Subkriteria dari IPK

\begin{tabular}{|c|c|c|c|c|c|c|c|}
\hline PK & & & & & \multirow{2}{*}{ PV } & Hasil Kali Matriks & $\begin{array}{c}\text { Pembagian } \\
(\lambda)\end{array}$ \\
\hline & A & B & C & D & & & \\
\hline A & 1,00 & 2,00 & 2,00 & 3,00 & 0,42 & 1,70 & 4,09 \\
\hline B & 0,50 & 1,00 & 2,00 & 2,00 & 0,27 & 1,11 & 4,10 \\
\hline C & 0,50 & 0,50 & 1,00 & 2,00 & 0,19 & 0,78 & 4,03 \\
\hline D & 0,33 & 0,50 & 0,50 & 1,00 & 0,12 & 0,49 & 4,06 \\
\hline \multicolumn{1}{|l|}{ TOTAL } & 2,33 & 4,00 & 5,50 & 8,00 & 1,00 & 4,08 & 16,28 \\
\hline
\end{tabular}

Lambda Max dengan rumus :

$$
\begin{aligned}
\lambda \max & =\frac{\Sigma \lambda}{\mathrm{n}} \\
& =\frac{16,28}{6} \\
& =4,07
\end{aligned}
$$


Menghitung Consistensy Indeks (CI) dengan rumus

$$
\begin{aligned}
\mathrm{CI} & =\frac{\lambda \max -\mathrm{n}}{\mathrm{n}-1} \\
& =\frac{4.07-6}{6-1} \\
& =0.02
\end{aligned}
$$

Menghitung Concistency Rasio (CR) dengan rumus :

$$
\begin{aligned}
\mathrm{CR} & =\frac{\mathrm{CI}}{\mathrm{IR}} \\
& =0,02 \\
& 0,24 \\
& =0,03
\end{aligned}
$$

- Menghitung Prioritas Subkriteria dari TOEFL

Tabel 3.8 Perhitungan Matriks Subkriteria dari TOEFL

\begin{tabular}{|c|c|c|c|c|c|c|c|}
\hline Toefl & & & & & PV & Hasi Kali Matriks & Pembagian \\
\hline & A & B & C & D & & & \\
\hline A & 1,00 & 2,00 & 3,00 & 5,00 & 0,48 & 1,94 & 4,02 \\
\hline B & 0,50 & 1,00 & 2,00 & 3,00 & 0,27 & 1,09 & 4,02 \\
\hline C & 0,33 & 0,50 & 1,00 & 2,00 & 0,16 & 0,63 & 4,00 \\
\hline D & 0,20 & 0,33 & 0,50 & 1,00 & 0,09 & 0,35 & 4,01 \\
\hline TOTAL & 2,03 & 3,83 & 6,50 & 11,00 & 1,00 & 4,02 & 16,06 \\
\hline
\end{tabular}

Menghitung Lambda Max dengan rumus :

$$
\begin{aligned}
\lambda \max & =\frac{\Sigma \lambda}{\mathrm{n}} \\
= & =\frac{6,06}{6} \\
& =4,01
\end{aligned}
$$

\begin{tabular}{|c|c|c|c|c|c|c|c|}
\hline Micoteachimg & & & & & PV & HASS DPERKALLAN MATRRSS. & EMBGGANND) \\
\hline & $A$ & B & $l$ & 0 & & & \\
\hline$A$ & 1,00 & 2,00 & 2,00 & 5,00 & 0,45 & 1.85 & 4,07 \\
\hline$B$ & 0,50 & 1,00 & 2,00 & 2,00 & 0,26 & 1,06 & 4,07 \\
\hline l & 0,50 & 0,50 & 1,00 & 2,00 & 0,18 & 0,74 & 4,06 \\
\hline 0 & 0,20 & 0,50 & 0,50 & 1,00 & 0,10 & 0,41 & 4,08 \\
\hline TOTAL. & 2,20 & 4,00 & 5,50 & 10,0 & 1,0 & 2,212 & 12,20 \\
\hline
\end{tabular}

Menghitung Consistensy Indeks (CI) dengan rumus :

$$
\begin{aligned}
\mathrm{CI} & =\frac{\lambda \max -\mathrm{n}}{\mathrm{n}-1} \\
& =\frac{4,01-6}{6-1} \\
& =0,00
\end{aligned}
$$

Menghitung Concistency Rasio (CR) dengan rumus :

$$
\begin{aligned}
\mathrm{CR} & =\frac{\mathrm{CI}}{\mathrm{IR}} \\
= & \frac{0,00}{1,24} \\
& =0,01
\end{aligned}
$$

- Menghitung Prioritas Subkriteria dari Microteaching

Tabel 3.9 Perhitungan Matriks Subkriteria dari Microteaching

Menghitung Lambda Max dengan rumus :

$$
\begin{aligned}
\lambda \max & =\frac{\Sigma \lambda}{\mathrm{n}} \\
= & \frac{12,20}{6} \\
& =4,07
\end{aligned}
$$

Menghitung Consistensy Indeks (CI) dengan rumus :

$$
\begin{aligned}
C I & =\frac{\lambda \max -n}{n-1} \\
& =\frac{4,07-6}{6-1} \\
& =0,02
\end{aligned}
$$

Menghitung Concistency Rasio (CR) dengan rumus :

$$
\begin{aligned}
\mathrm{CR} & =\frac{\mathrm{CI}}{\mathrm{IR}} \\
= & \frac{0,02}{1,24} \\
& =0,02
\end{aligned}
$$


- Menghitung Prioritas Subkriteria dari TPA

Tabel 3.10 Perhitungan Matriks Subkriteria dari TPA

\begin{tabular}{|c|c|c|c|c|c|c|c|}
\hline TPA & & & & & & & \\
\hline & A & B & C & D & PV & HASLIPERKALLANMATRIS & PEMBAGIAN(A) \\
\hline A & 1,00 & 2,00 & 4,00 & 5,00 & 0,50 & 2,02 & 4,05 \\
\hline$B$ & 0,50 & 1,00 & 2,00 & 4,00 & 0,28 & 1,13 & 4,03 \\
\hline$C$ & 0,25 & 0,50 & 1,00 & 2,00 & 0,14 & 0,57 & 4,03 \\
\hline$D$ & 0,20 & 0,25 & 0,50 & 1,00 & 0,08 & 0,32 & 4,01 \\
\hline TOTAL & 1,95 & 3,75 & 7,50 & 12,00 & 1,00 & 4,04 & 16,11 \\
\hline
\end{tabular}

Lambda Max dengan rumus :

$$
\begin{aligned}
\lambda \max & =\frac{\Sigma \lambda}{n} \\
& =\frac{16,11}{6} \\
& =4,03
\end{aligned}
$$

Menghitung Consistensy Indeks (CI) dengan rumus :

$$
\begin{aligned}
\mathrm{CI} & =\frac{\lambda \max -\mathrm{n}}{\mathrm{n}-1} \\
& =\frac{4,03-6}{6-1} \\
& =0,01
\end{aligned}
$$

Menghitung Concistency Rasio (CR) dengan rumus :

$$
\begin{aligned}
\mathrm{CR} & =\frac{\mathrm{CI}}{\mathrm{IR}} \\
& =\frac{0,01}{1,24} \\
& =0,01
\end{aligned}
$$

- Menghitung Prioritas Subkriteria dari Wawancara

Tabel 3.11 Perhitungan Matriks Subkriteria dari Wawancara

\begin{tabular}{|c|c|c|c|c|c|c|c|}
\hline \multicolumn{2}{|l|}{ Wawancar' } & & & & & & \\
\hline & A & B & C & D & PV & HASIL PERKALLAN MATRIIS & PEMBAGIAN ( $\lambda$ ) \\
\hline A & 1,00 & 2,00 & 5,00 & 5,00 & 0,51 & 2,10 & 4,11 \\
\hline B & 0,50 & 1,00 & 2,00 & 5,00 & 0,29 & 1,17 & 4,05 \\
\hline C & 0,20 & 0,50 & 1,00 & 2,00 & 0,13 & 0,52 & 4,08 \\
\hline D & 0,20 & 0,20 & 0,50 & 1,00 & 0,07 & 0,30 & 4,03 \\
\hline TOTAL & 1,00 & 3,70 & 8,50 & 13,00 & 1,00 & 4,08 & 16,27 \\
\hline
\end{tabular}

Lambda Max dengan rumus :

$$
\begin{aligned}
\lambda \max & =\frac{\Sigma \lambda}{\mathrm{n}} \\
& =\frac{16,27}{6} \\
& =4,07
\end{aligned}
$$

Menghitung Consistensy Indeks (CI) dengan rumus :

$$
\begin{aligned}
C I & =\frac{\lambda \max -n}{n-1} \\
& =\frac{4,07-6}{6-1} \\
& =0,02
\end{aligned}
$$

Menghitung Concistency Rasio (CR) dengan rumus :

$$
\begin{aligned}
\mathrm{CR} & =\frac{\mathrm{CI}}{\overline{\mathrm{IR}}} \\
& =\frac{0,02}{1,24} \\
& =0,02
\end{aligned}
$$

- Menghitung Prioritas Subkriteria dari Pengalaman

Tabel 3.12 Perhitungan Matriks Subkriteria dari Pengalaman

\begin{tabular}{|c|c|c|c|c|c|c|c|}
\hline Pengalaman & & & & & & & \\
\hline & A & B & C & D & PV & HASIL PERKALLAN MATRIKS & PEMBAGIAN (A) \\
\hline A & 1,00 & 2,00 & 4,00 & 6,00 & 0,51 & 2,06 & 4,02 \\
\hline$B$ & 0,50 & 1,00 & 2,00 & 4,00 & 0,28 & 1,10 & 4,01 \\
\hline$C$ & 0,25 & 0,50 & 1,00 & 2,00 & 0,14 & 0,55 & 4,01 \\
\hline$D$ & 0,17 & 0,25 & 0,50 & 1,00 & 0,07 & 0,30 & 4,00 \\
\hline TOTAL & 1,92 & 3,75 & 7,50 & 13,00 & 1,00 & 4,01 & 16,04 \\
\hline
\end{tabular}

Lambda Max dengan rumus :

$$
\begin{aligned}
\lambda \max = & \frac{\Sigma \lambda}{\mathrm{n}} \\
& =\frac{16,04}{6} \\
& =4,01
\end{aligned}
$$

Menghitung Consistensy Indeks (CI) dengan rumus :

$$
\begin{aligned}
\mathrm{CI} & =\frac{\lambda \max -\mathrm{n}}{\mathrm{n}-1} \\
& =\frac{4,01-6}{6-1} \\
& =0,00
\end{aligned}
$$


Menghitung Concistency Rasio (CR) dengan rumus :

$$
\begin{aligned}
\mathrm{CR} & =\underset{\mathrm{IR}}{\mathrm{CI}} \\
= & =\frac{000}{1,24} \\
& =0,00
\end{aligned}
$$

\section{HASIL DAN PEMBAHASAN}

4.1 Alat dan bahan penelitian

Perangkat lunak yang digunakan dalam penelitian ini adalah :

1. Database MySql sebagai penyimpanan data.

2. Borland Delphi 7.0 yang digunakan sebagai editor dan merancang desain tampilan Aplikasi.

\section{Diagram alir data}

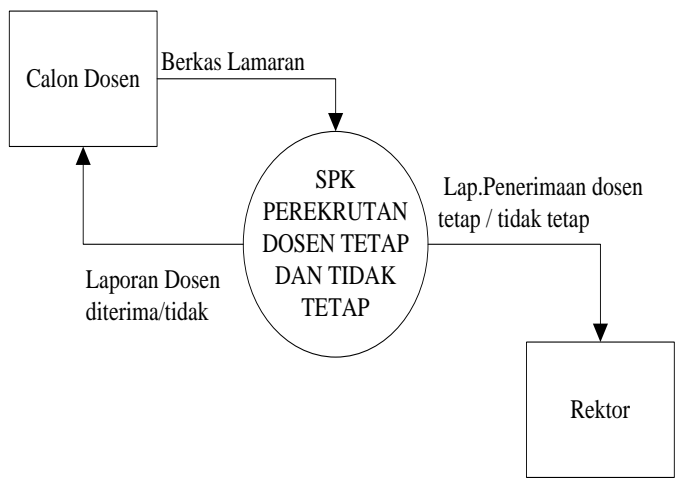

Gambar 4.1. Diagram Konteks Sistem SPK

\subsection{Pembahasan Program}

\section{Tampilan Input Login}

Ketika pertama kali program aplikasi ini dijalankan, akan tampil sebuah form menu login. Form ini digunakan untuk melakukan login bagi pengguna. Untuk bisa menggunakan Program aplikasi ini.

\section{Login User}

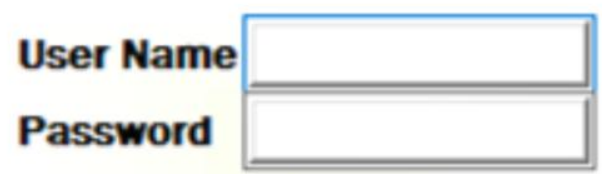

\section{Login Cancel}

Gambar 4.2 Tampilan Menu Login
2. Tampilan Halaman Menu Utama

Saat pertama kali dibuka, akan tampil halaman utama dengan halaman yang terdapat disebelah kiri atas. Tampilan form menu utama pada Gambar dibawah ini.

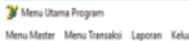 \\ MENU UTAMA PROGRAM \\ SISTEM PENDUKUNG KEPUTUSAN PEREKRUTAN DOSEN TETAP DAN TIDAK TETAP DI UNIVERSITAS MEGOU PAK TULANG BAWANG \\ MENGGUNAKAN METODE ANALYTICAL. HIERARCHY PROCESS (AHP)}

Gambar 4.3 Tampilan Halaman Menu Utama

\section{Tampilan Form Input Data Kriteria}

Ketika user memilih form input data Kriteria maka akan menampilkan informasi data Kriteria yang akan digunakan untuk menentukan dosen tetap dan tidak tetap. Tampilan form input data Pegawai terdapat pada gambar di bawah ini.

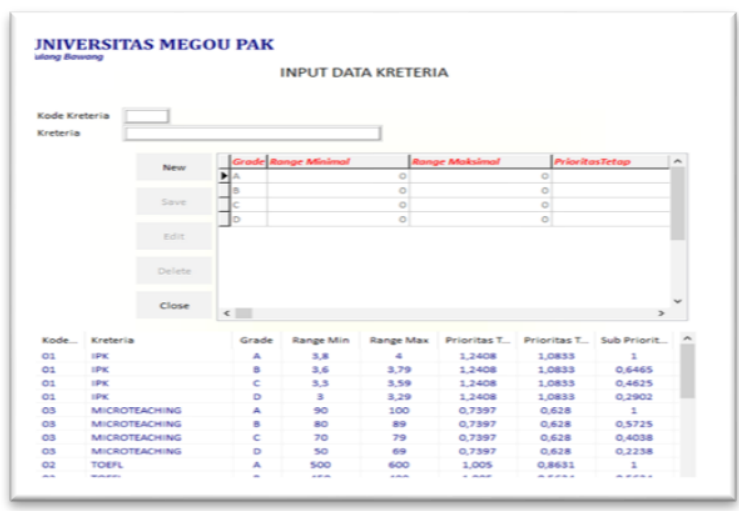

Gambar 4.4 Tampilan Form Input Data Kriteria

4. Tampilan Form Data Berkas Lamaran Ketika memilih menu Form Data Berkas Lamaran maka halaman ini mengimputkan seluruh biodata pelamar yang sesuai dengan ketentuan instansi. 


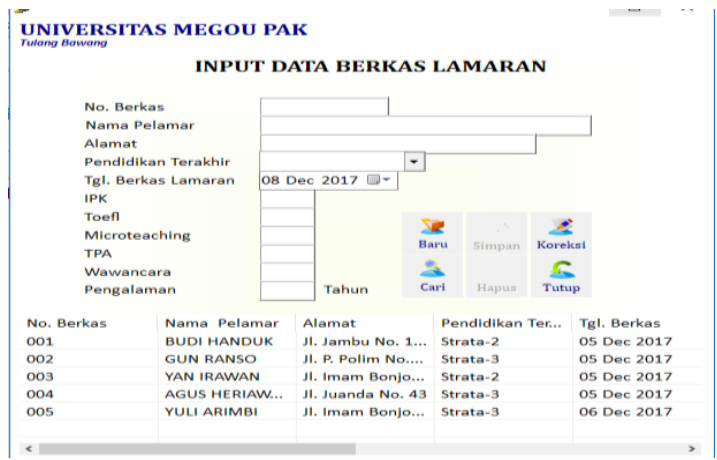

Gambar 4.5 Tampilan Form Input Data Berkas Lamaran

5. Tampilan Proses Seleksi Penerimaan Calon Dosen

Ketika memilih menu Proses Seleksi Penerimaan Calon Dosen maka halaman ini mengimputkan seluruh proses seleksi penerimaan dosen.

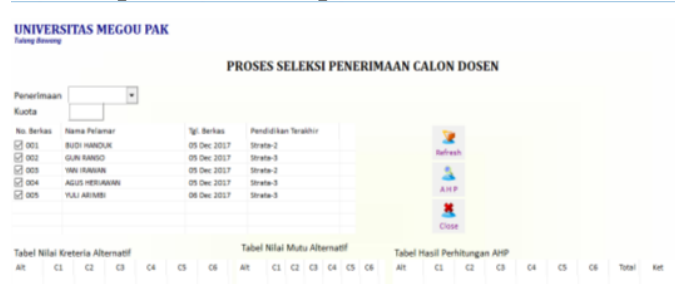

Gambar 4.6 Tampilan Proses Seleksi Penerimaan Dosen

6. Tampilan Laporan Hasil Seleksi Penerimaan Dosen

Halaman ini adalah hasil keputusan dari perhitungan yang telah dilakukan dalam melakukan seleksi penerimaan dosen dengan menggunakan metode AHP.

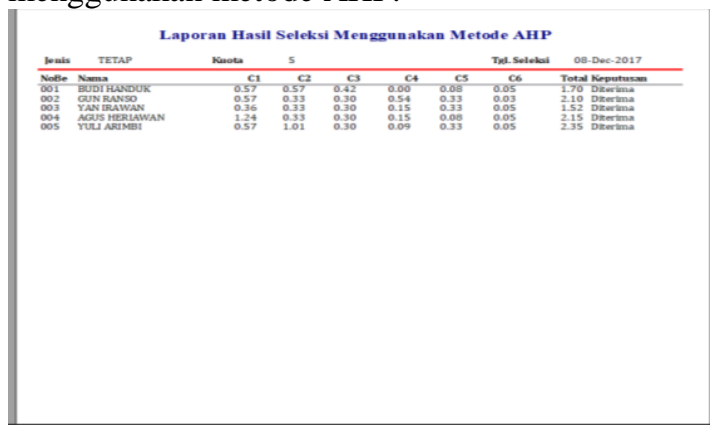

Gambar 4.7 Tampilan Hasil Seleksi Penerimaan Dosen

\section{Kesimpulan dan Sarasn}

\section{KESIMPULAN}

Berdasarkan hasil penelitian maka diambil kesimpulan sebagai berikut :

1. Program Sistem Pendukung Keputusan Perekrutan Dosen Tetap dan Tidak Tetap dengan Menggunakan Metode AHP ini memiliki keamanan data berupa Administrator

2. Sistem Pendukung Keputusan Perekrutan Dosen Tetap dan Tidak Tetap dengan Menggunakan Metode AHP telah dilakukan secara terkomputerisasi dengan program Aplikasi yang menerapkan metode AHP.

3. Penilaian dengan metode AHP tidak dapat di terapkan apabila hanya memiliki satu kandidat saja karena metode AHP memberikan hasil perengkingan dari seluruh kandidat-kandidat yang ada.

4. Sistem ini dapat mempermudah Universitas Megow Pak Tulang Bawang dalam menentukan dosen tetap dan tidak tetap secara Objektif.

5. Hasil akhir dari suatu sistem ini hanya sebagai acuan dalam menentukan kandidat yang ada namun keputusan terbesar tetap berdasar pada Pimpinan.

\section{SARAN}

Sistem Pendukung Keputusan yang dibuat oleh penulis ini, baik dalam perancangan maupun implementasi masih banyak kekurangan dan kelemahannya, oleh karena itu disarankan :

1. Perlunya pengembangan dalam penggunaan suatu metode agar proses perhitungan dapat lebih rinci dan hasil perengkingan lebih mendapatkan hasil yang maksimal.

2. Untuk meningkatkan efeksifitas dan efisiensi kerja perlu pertimbangan pergantian sistem yang ada pada saat ini menjadi sistem yang terkomputerisasi agar pengambilan keputusan perekrutan dosen tetap dan tidak tetap dapat lebih efektif.

3. Penyimpanan data yang digunakan oleh aplikasi ini dapat dikembangkan lagi dengan menggunakan database yang keamanannya lebih terjaga.

\section{DAFTAR PUSTAKA}

[1] Ahmad Bustami, 1999, "Cara Mudah Belajar Internet, Homesite, dan HTML”, Penerbit Dinastindo- Jakarta. 
[2] Depdiknas. 2009. Pengertian Dosen Definisi Ciri Menurut Para Ahli. Hidayati. Nurtriana, 2016, Analisa Penerimaan Dosen Baru dengan Menggunakan SAW (Simple Additive Weighting), Vol. 14 No. 1/Juli 2016.

[3] I Dewa Made Adi Baskara dan Anak Agung Gede Bagus Ariana, 2014, "Sistem Pendukung Keputusan Seleksi Penerimaan Dosen Tetap Yayasan Dengan Metode FUZZY-AHP”, Denpasar: Jurnal Ilmiah Nero Vol.1, No.3.

HIm 1-9.

[4] Ikmah, 2016, "Sistem Pendukung Keputusan Seleksi Penerimaan Dosen Menggunakan Metode TOPSIS", Yogyakarta : Seminar Nasional Teknologi Informasi dan Multimedia.

[5] Kusrini, 2016" Konsep dan Aplikasi Sistem Pendukung Keputusan ",

M. Farid Azis, 2001 "Belajar Sendiri Pemrograman PHP 4”, Penerbit PT Elex Media Komputindo-Jakarta.

[6] Peraturan PemerintahNo.37 Tahun 2009 Tentang Dosen. Ristekdikti. go. id. Jakarta

[7] Raharjo. Dwi, 2015, “Sistem Penunjang Keputusan Penerimaan Dosen dengan Metode Analytical Hierarchy Process", Vol.5 No.1/Maret 2015.

[8] Saaty. T, 2000, Fundamentals of Decision Making and Priority Theory With the Analytical Hierarchy Process, RWS Publications, New York.

[9] Saaty. T, 2012, Models, Methods, Concepts \& Applications of the Analytic Hierarchy Process, Springer Science \& Business Media, London.

[10] Surya. Desayu, Kompetensi Dosen Terhadap Standarisasi Layanan Kepada Mahasiswa, Vol.6, No.2.

[11] Syaifullah, 2010, Pengenalan Metode $A H P$, PT.Gramedia, Jakarta. 
